\title{
Tamil Nadu Traditional Food - A Remedy for Coronavirus (Neuropathogen) and Other Infections
}

\section{Sivakumar J T Gowder*}

\section{Department of Management of Science and Technology Development, Ton Duc} Thang University, Ho Chi Minh City, Vietnam

*Corresponding Author: Sivakumar J T Gowder, Department of Management of Science and Technology Development, Ton Duc Thang University, Ho Chi Minh City, Vietnam.
Received: February 03, 2020

Published: February 21, 2020

(C) All rights are reserved by Sivakumar J T

Gowder.
Coronaviruses are a group of deadly viruses that cause ordinary cold to even severe diseases such as- SARS- Severe Acute Respiratory Syndrome; MERS -Middle East Respiratory Syndrome; pneumonia; and kidney failure. These coronaviruses are initially reported in the Wuhan city of China. Now, it is considered to be the most dangerous virus and is threatening across the world. Recently, researchers reveal the existence of a direct association between coronavirus and certain neurological complications (Alzheimer's, Parkinson's, etc.) in humans. Usually, these viruses are transmitted from animals to humans. For example, SARS - Transmitted from civet cats to humans; and MERS- transmitted from camels to humans. From available reports, scientists suspect that coronavirus may be transmitted from snakes since intake of snakes is more common in China.

Tamil Nadu (a state in the Southern Part of India), has typical food items that have potential medicinal value. Tamil Nadu is also a hub for all medicinal plants. From various sources, we can notice that there are medicinal plants or traditional medical system available in Tamil Nadu for the treatment of almost all types of diseases. "Rasam," one of the famous food items in Tamil Nadu, is a kind of tasty soup that is more common in the villages of Tamil Nadu. This soup is an ingredient of garlic, shallots, horse gram, curry leaves, pepper, dry chillies, coriander seeds, jeera, dry ginger, asafoetida, turmeric, mint leaves, etc., in addition to other ingredients depending on the type of rasam people require according to their necessities. People also use tomatoes in preparing this item. We can notice, almost all the above ingredients have medicinal values, especially, antimicrobial activity in addition to serving as antioxidants. This rasam, not only rich in vitamins but also contains a wide array of minerals. Usually, this tasty soup can be served with rice or savoured after meal. In Tamil Nadu, especially in rural areas, people consider this rasam as a potential traditional medicine for cold and flu. In addition to it, people also consume this rasam to get rid of body ache and problems concerned with digestion.

In this article, I have the liberty to write my own experiences concerned with traditional village culture in addition to my knowledge in this area of medical sciences to consider this soup- rasam, as a potential food item to prevent viral infections. While growing in my village- Nanjanad, in Tamil Nadu, I had the great experience of having our traditional food items which I used to follow even now (while on travel or living abroad). Whenever, I used to have cold or flu, my beloved mother took care of me in different ways including preparing good quality rasam. Whenever I had rasam with "Saadam" (cooked rice), I would be relieved from the illness (cold or flu) in a period of 24 to 48 hours. I can understand from my childhood, people in our village or other villages do the same (taking rasam with rice) while in cold or flu. After having become a scientist, these days, I strictly follow the same procedure whenever I have cold or flu. In traditional medicine, it is assumed that combinations of many products/ ingredients will give good results since we can get constituents of all products.

In this critical situation of threatening of this killer virus, that is, coronavirus, I suggest the people infected with this virus in China or other affected parts of the world to try this rasam (with rice as their food) at certain extent to get rid of this infection in a reliable period. People can get the recipe in the internet sources. Moreover, all killer viruses dwell in animals and hence, people should avoid 
eating meat products in this viral infected time period, even-though they used to have it. In addition to all, we should also follow other preventive measures to get rid of it.

\section{Assets from publication with us}

- Prompt Acknowledgement after receiving the article

- Thorough Double blinded peer review

- Rapid Publication

- Issue of Publication Certificate

- High visibility of your Published work

Website: https://www.actascientific.com/

Submit Article: https://www.actascientific.com/submission.php

Email us: editor@actascientific.com

Contact us: +919182824667 